\title{
べた基礎を有する軽量建物を想定した免震方式の 3 軸振動台実験 THREE DIMENSIONAL SHAKING TABLE TESTS ON A BASE-ISOLATION SYSTEM FOR LIGHT-WEIGHT BUILDINGS
}

\author{
堀 昭夫* \\ Akio HORI
}

\begin{abstract}
Three-dimensional shaking table tests were carried out for a new base-isolation system of a lightweight building with a mat foundation. The new system uses resin balls between the mat and an under-mat reinforced concrete slab. A type using fiber-reinforced cement boards and phenol resin balls caused a load concentration in its virgin state and amplified its response in case of a small input. Another type with layers of polystyrene foam, the cement board, polystyrene balls and the cement board absorbed relative unevenness between the moving mat and the under-mat slab and decreased its acceleration under about $40 \mathrm{~cm} / \mathrm{sec}^{2}$.
\end{abstract}

Keywords: base isolation, mat foundation, shaking table, ball, resin, test 免震、べた基礎、振動台、球、樹脂、実験

\section{1.はじめに}

軽量建物の免震化では、通常の中層建物の免震化とは異なるいく つかの問題を考慮寸る必要がある。問題の内容は文献 ${ }^{1)}{ }^{2)}$ でも述 ベられているが、(1)地震時の免震性能を良くすると風荷重が地震荷 重を上回って暴風時対策が必要となる事、(2)強風時の摇れによる居 住性の低下を防ぐ必要がある事、(3)壁式構造や戸建住宅では標準的 なスパンが小さいので通常の免震装置間隔だと上部構造や基礎を補 強する必要が生じる事、(4)仮に積層ゴムを用いると固有周期の関係 でゴムの断面積が小さくなって積層ゴムの座屈防止対策が必要とな る事、等があげられる。軽量建物や戸建住宅の免震化に関しては、 既に積層ゴムやす心゙り、転がりを利用した各種免震装置が開発・試

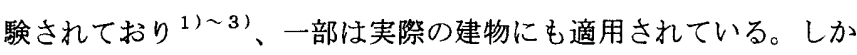
しながら軽量建物や戸建住宅は、着工総数が多いにも拘わらず免震 化された例が中層建物に比べてむしろ少ない" ${ }^{1)}$ のが現状となってい る。これは建物工事費用に占める免震化のための費用が大きいため と言われており、性能が良くかつ簡便な免震方式が求められている。 本報では、べた基礎を有する軽量建物や戸建住宅を対象に、べた 基礎とべた基礎の下に設けた鉄筋コンクリートスラブの間に樹脂球 を挿入した新たな転がり免震方式について、3 軸振動台実験を行っ た。実験結果に基ついて提案する免震方式は、べた基礎下に鉄筋コ ンクリートスラブを設ける以外は上部構造や基礎の補強を特に必要 とせず、施工性に配慮した免震方式となっている。

\section{2. 免震方式および試験体}

実験対象とする免震方式 F25 タイプおよび P6 タイプの概要を図 -1(a)および(b)に示す。免震方式は、布基礎と同様の立ち上がり部 分を有するべた基礎(以下、上基礎と呼ぶ)の下に、鉄筋コンクリー 卜製の基礎板(以下、下基礎と呼ぶ)を設けて、その間に樹脂球を敷 き詰めた方式とした。下基礎および上基礎の平面形状を図ー 2 に示 す。下基礎は平面寸法が $5.65 \mathrm{~m} \times 4.10 \mathrm{~m}$ で、振動台に固定するため の鉄骨架台を含む計算重量が $11.4 \mathrm{t}$ であり、上面は金ゴテ仕上げし てある。上基礎は平面寸法が $4.71 \mathrm{~m} \times 3.80 \mathrm{~m}$ であり、戸建住宅基礎 と同様の立ち上がり部分を有する。ただし上基礎平面は計測用およ びブレーキ装置取付用の計 4 つの開口を有する。上基礎の計算重量 は、上基礎側のボードを含めて F25 タイプで 9.7t、P6 タイプで $9.6 \mathrm{t}$ であり、上基礎下面の面積は $13.3 \mathrm{~m}^{2}$ である。上基礎には付加重量 として計 $5.2 \mathrm{t}$ の鋼板を固定した(図ー 2 参照)。このため免震層の平

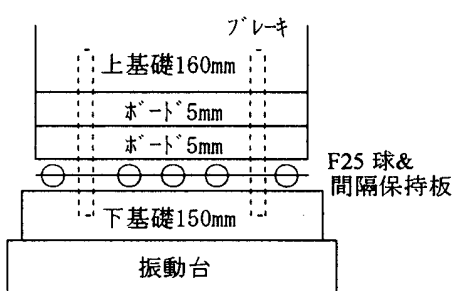

(a) F25 タイブ

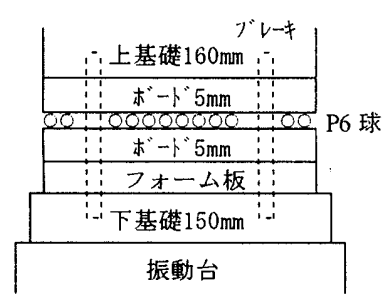

(b) P6 タイプ
図- 1 免震方式 $の$ 概要

\footnotetext{
*ハザマ技術研究所 主任研究貝・博士 (工学)

Chief Research Engineer, T.R.I., Hazama Corp., Dr. Eng.
} 
均面圧は $1.1 \mathrm{tf} / \mathrm{cm}^{2}$ 程度となり、べた基礎を有する戸建住宅での值 (文献4)を参考に建物重量を $0.45 \mathrm{t} / \mathrm{m}^{2}$ とすると $0.9 \mathrm{t} / \mathrm{m}^{2}$ 程度になる) と 近い。両基礎のコンクリートは設計基準強度 $270 \mathrm{kgf} / \mathrm{cm}^{2}$ のものを 用いた。なお本実験では上基礎と下基礎間の相対不陸がより大きく なるよう、下基礎上で製作した上基礎を下基礎に対して平面的に 180 回転させて振動台上に設置した。

上基礎の下面には厚さ $5 \mathrm{~mm}$ のセメント系繊維補強板(フレキシブ ルボード、以下ボードと略す)を貼付した。ボードは実際の施工で は型枠として使用してコンクリートと一体化されるが、本実験では 上基礎下面の既存ボードの下に新たなボードを厚手の両面テーブに より貼付した。実験の都合で F25 タイプではボードを 2 層に貼付 し、P6タイブではそのうちの外側 1 層をはがして実験した。

本実験では、転がり材が異なる2 種のタイブを試験した。F 25 タ イブでは、ガラス繊維入りフェノール樹脂の $25 \mathrm{~mm}$ 球(以下、F 25 球と呼ぶ)を間隔保持板にはめ込んで綐横ほぼ $12 \mathrm{~cm}$ 間隔で計約 1060 個を上基礎の下に配した(写真一 1(a))，一方、P6 タイプでは ポリスチレンの $6 \mathrm{~mm}$ 球 (平均重量 $0.114 \mathrm{~g}$ 、以下、P6 球と呼ぶ)を密

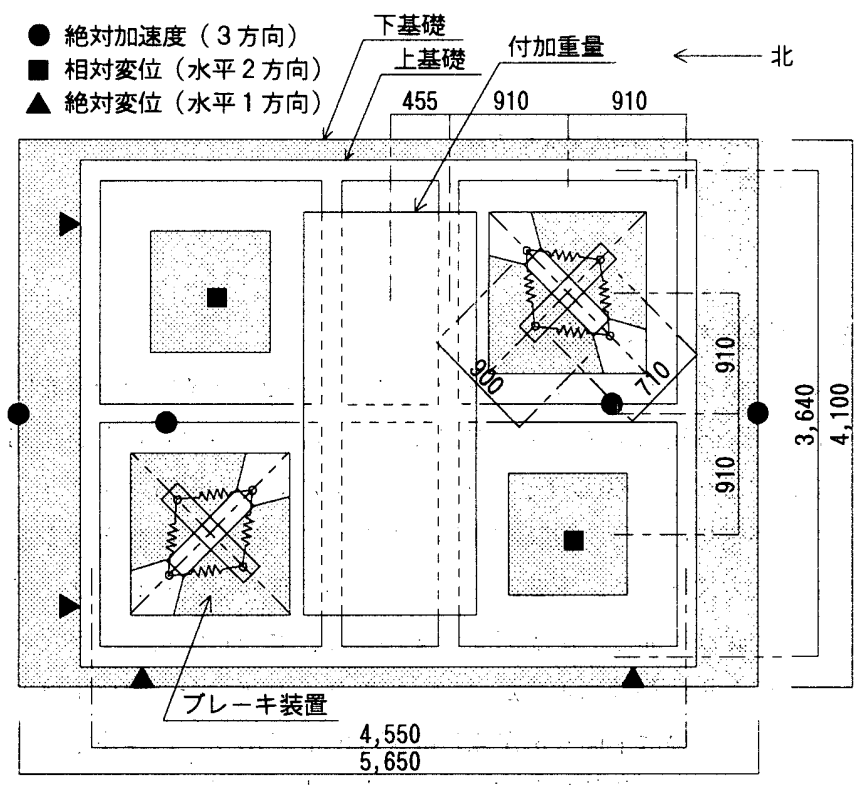

図-2 試験体平面形状

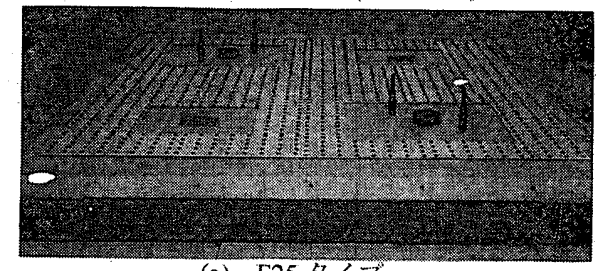

(a) F25 タイ:
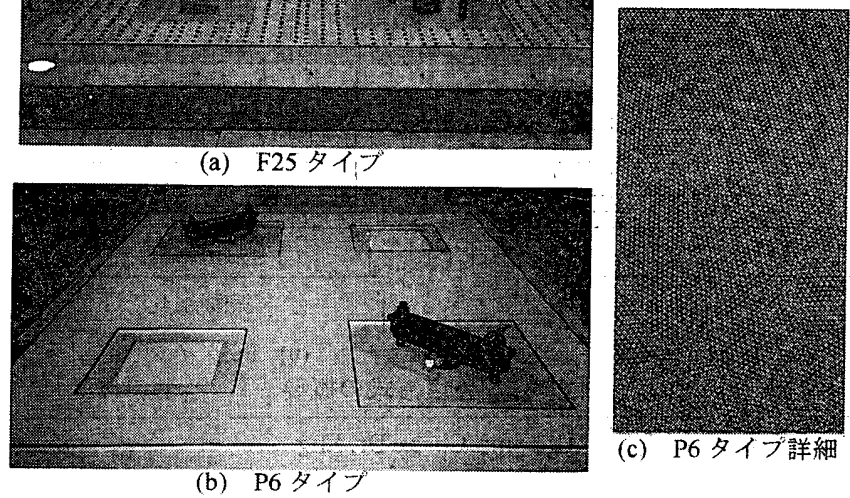

写真一 1 転がり材の敷き並べ状況
に近い状態で同じ範囲に敷き詰めた(写真- 1(b),(c))。P6 球の敷き 詰め重量は計 $43.5 \mathrm{~kg}$ (約 38 万個、敷詰密度 $3.27 \mathrm{~kg} / \mathrm{m}^{2}$ )であった。

P6 タイブでは、下基礎上面と上基礎下面の間の相対不陸の吸収 および荷重集中の低減を意図して、下基礎の上に不陸吸収層を設け た。加振時に上基礎が下基礎に対して移動すると、両基礎間の相対 不陸が変化するが、不陸吸収層はその吸収をも意図した。不陸吸収 層には厚 $20 \mathrm{~mm}$ の押出法ポリスチレンフォーム保温板 1 種 b (以下、 フォーム板と呼ぶ)を用いた。フォーム板はJIS A9511 に圧縮強さ や燃焼性が規定されている。押出法ポリスチレンフォームは、軽量 盛土工法(EPS 工法)において大きな耐圧強度が必要な場合にも用い

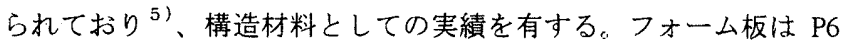
球と比べて強度が小さいため、フォーム板と P6 球の間にはボード を敷き並べた。ただしボードの敷き並べは、実施工に执いて上下 2 枚のボードの間に P6 球を詰め込んだまま現場で敷き並べる場合を 考えて、各ボード間に $3 \mathrm{~mm}$ 程度の隙間をあけて並べた。また P6 球の外周位置のボード上には市販のスポンジ付きテーブを貼付して、 加振時には P6 球が乗り越えるが、非加振時には P6 球がこぼれな いようにした。一方F25 タイプでは、F25 球および保持板をボード や不陸吸収層を介する事なく直接、 上基礎のコンクリート面上に置 いた。

試験体には、暴風・強風時に免震部分の変形を拘束する事を想定 した摩擦ブレーキ装置を2 ヶ所に取り付けた(図ー 2 参照)。同装置 は上基整側に固定した鋼板と下基礎側に固定した鋼板を摩擦板を介 して交互に積ねて、積ねた部分に油圧ジャッキで押圧力を与えてブ レーキカを生じさせる方式となっている。暴風時に大きな地震が起 きる確率は非常に小さいと考えられるが、その場合を想定したブレ 一キ作動下の加振実験も行った。免震部分の拘束に摩擦ブレーキを 用いた理由は、(1)地震後の残留変位は必ずしも0でないがその状態 でも拘束できること、(2)もしクリアランスが大きい拘束方法にする と風摇机が止まらないこと、(3)地震が来ても特に状態変化させる必 要がないこと、(4)拘束状態で地震が来ても損傷しないこと、等であ る。なお本試験では、油圧を用いて 2 ヶ所のブレーキに等しい摩擦 面押圧力を与えておき、油圧弁を閉じた状態で加振した。

加振後の残留変位の低減を目的として、2ヶ所のブレーキ装置に はブレーキとは独立にそれぞれ 4本の引張ば杍を菱形状に組み込ん だ(図ー 2 参照)。各ばねの定格は、剖性 4.5kgf/cm; ストローク0て +250mm であり、圧縮力が作用しないような方法で取り付けた。変 位が小さい時のば的㐩性計算值は、菱形状 4 本では強軸方向 $5.43 \mathrm{kgf} / \mathrm{cm}$ 、弱軸方向 $3.57 \mathrm{kgf} / \mathrm{cm}$ 、゙あるが、試験体全体では南北方 向·東西方向ともに $9 \mathrm{kgf} / \mathrm{cm}$ となる。試験体全体でのば凮心は、 菱形による強軸: 弱軸の関係で平面中心から東に $282 \mathrm{~mm}$ 、南に $188 \mathrm{~mm}$ の位置にある。

\section{3. 素材試験}

中央集中線荷重によるボードの曲げ試験の結果を表ー1および図 一3に示す。ただし図の繸軸は、弹性時の関倸を用いて曲げモーメ ントを曲げ応力度に換算し、横軸も同様に変位を縁歪に換算してあ る。.゙ホードの曲げ強度は、長尺方向 $35 \mathrm{MPa}$ 程度、短尺方向 47 〜 $54 \mathrm{MPa}$ であり、通常のコンクリートの圧縮強度並の值を示した。 しかし破断面の目視では層状のはがれが板厚方向に認められ、製造 
方法にも関係すると思われるが板厚方向には繊維がより少ないと思 われた。なおボードは高圧プレス成型されており目視では表面が平 滑である。

フォーム板の圧縮試験結果を表ー 2 および図ー 4 に示す。降伏強 度は $0.29 \mathrm{MPa}$ 程度であるが、これは $1 \mathrm{~m}^{2}$ あたり $30 \mathrm{tf}$ に相当し、軽 量建物のべた基礎面積あたりの平均重量に比べれば非常に大きい。

F25 球の圧縮試験結果を図一 5 の実線および表一 3 に示す。最大 荷重は 19 〜 35k とばらついたが、いずれも突然爆裂して破壊し た(図中点)。“このうち、最大荷重が小さかった No.3 は半球状金 型の接合面に沿った爆裂が認められ、圧縮方向が関係している可能 性がある。F25 球の上下にボードを挿入して圧縮した場合の結果を 同図に点線で示す。ボードには直径 $12 \mathrm{~mm}$ の球面状の凹みが見ら れ(写真一2)、荷重 $47 \mathrm{kN}$ で F25 球が突然爆裂した。なお爆裂の原

\begin{tabular}{|c|c|c|c|c|}
\hline \multicolumn{2}{|c|}{ 表 -1} & \multicolumn{3}{|c|}{$\begin{array}{l}\text { ボードの曲げ } \\
\text { 試験結果 }\end{array}$} \\
\hline \begin{tabular}{|l} 
方 \\
向
\end{tabular} & No & $\begin{array}{l}\text { 板厚 } \\
(\mathrm{mm})\end{array}$ & $\begin{array}{l}\text { 曲げ } \\
\text { 強度 } \\
\text { (MPa) }\end{array}$ & $\begin{array}{l}\text { 弾性 } \\
\text { 係数 } \\
(\mathrm{GPa})\end{array}$ \\
\hline \multirow{3}{*}{$\begin{array}{l}\text { 長 } \\
\text { 尺 }\end{array}$} & 1 & 4.96 & 34.5 & \multirow{3}{*}{15.9} \\
\hline & 2 & 4.96 & 35.5 & \\
\hline & 3 & 4.94 & 36.4 & \\
\hline \multirow{3}{*}{ 短 } & 1 & 5.01 & 46.8 & 17.0 \\
\hline & 2 & 5.08 & 50.0 & 17.6 \\
\hline & 3 & 5.07 & 54.0 & 18.5 \\
\hline
\end{tabular}

表一 2
\begin{tabular}{|c|c|c|c|c|} 
フォーム板の \\
圧縮試験結果
\end{tabular}
\begin{tabular}{|c|c|c|c|c|}
\hline No & $\begin{array}{l}\text { 板厚 } \\
(\mathrm{mm})\end{array}$ & $\begin{array}{l}\text { 丕速 } \\
\text { 度 }(1 / \\
\min )\end{array}$ & $\begin{array}{l}\text { 降伏 } \\
\text { 強度 } \\
(\mathrm{MPa})\end{array}$ & $\begin{array}{l}\text { 弹性 } \\
(\mathrm{MPa})\end{array}$ \\
\hline 1 & 20.5 & 0.10 & 0.292 & 6.5 \\
\hline 2 & 20.5 & 0.24 & 0.301 & 8.3 \\
\hline 3 & 20.5 & 0.24 & 0.279 & 8.3 \\
\hline
\end{tabular}

表 $-3 \quad \begin{array}{r}\text { F25 球の圧縮 } \\
\text { 試験結果 }\end{array}$
\begin{tabular}{|c|c|c|}
\hline No & $\begin{array}{c}\text { 直径 } \\
(\mathrm{mm})\end{array}$ & $\begin{array}{c}\text { 最大荷重 } \\
(\mathrm{kN})\end{array}$ \\
\hline 1 & 24.9 & 34.6 \\
\hline 2 & 24.9 & 26.0 \\
\hline 3 & 24.9 & 19.2 \\
\hline 4 & 24.9 & 28.3 \\
\hline 5 & 24.9 & 28.6 \\
\hline
\end{tabular}

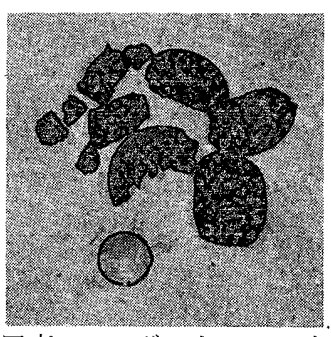

写真 -2 ボードの凹みと F25 球の爆裂

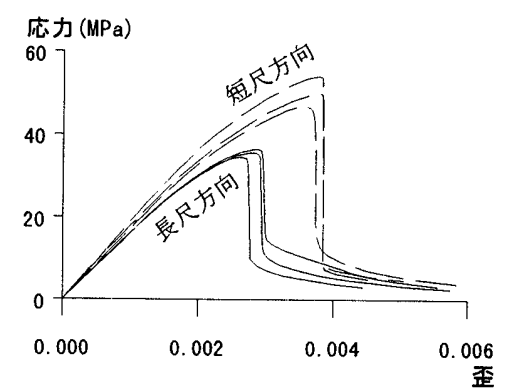

図一 3 ボードの曲げ試験結果と相似 な応力一歪関係
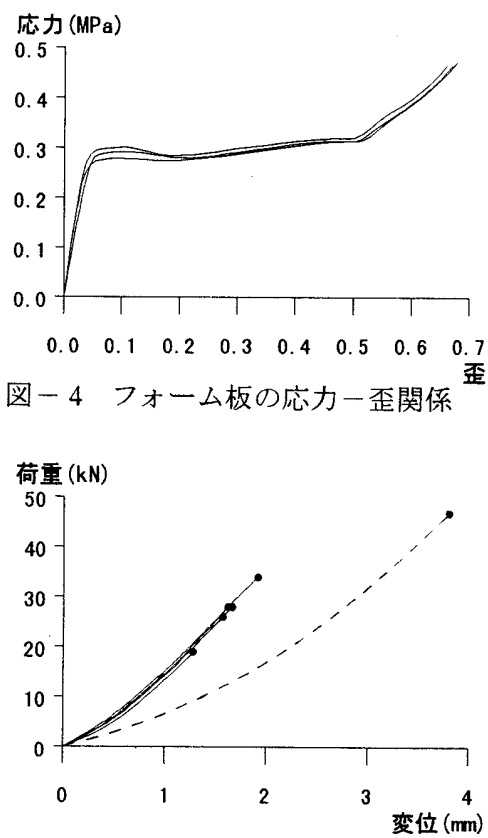

図-5 F25 球の圧縮試験結果

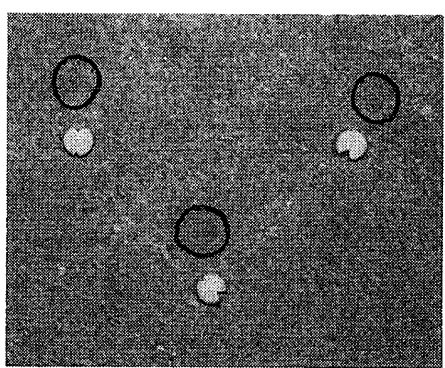

写真ー 3 P6 球の割れとつぶれ
因としては、F25 球の材料が熱硬化性樹脂である事、ガラス瀻維入 りである事が考えられる。

P6 球の圧縮試験結果を図一 6 の実線および表一 4 に示す。降伏 荷重は 760 ～830N であったが、降伏以後も割れおよび接触面の拡 大を生じながら荷重が上昇した。P6 球の上下にボードを㨂入して 圧縮した場合の結果を同図に点線で示すが、初期剛性がやや小さく なった点を除けば結果はあまり変わらない。P6 球は素材試験と同 様に割れてつぶれたが、ボードは接触面がやや黒ずんだ程度で目視 できる変形はなかった(写真－3)。

P6 タイブと同順に、ボード(150mm 角)、フォーム板(100mm 角)、 ボード(150mm 角)、および P6 球を重齐た状態で圧縮試験を行った。 P6 球が過少になった場合を想定して、P6 球の個数は 1 個、2 個、 または 4 個とし、図ー7 に示す平面位置に置いた。試験結果を図一 8 に実線で示す。ただし荷重は P6 球 1 個あたりの荷重に換算して ある。破線は素材試験結果を示すが、フォーム板の結果は断面積 $25 \mathrm{~cm}^{2}$ の場合に換算して P6 球 4 個の試験と対応させた。本試験の 結果を以下にまとめる。

(1) P6 球 1 個の試験では、P6 球が素材試験と同様に割れてつぶれた が、荷重 $1400 \mathrm{~N}$ 程度でボードが押し抜き破壊した。P6 球側のボ 一ドの凹み領域は P6 球の大きさと一致したが、裏側では直径 $40 \mathrm{~mm}$ 程度にわたる盛り上がりが見られた(写真一 4$)$ 。ボードの 内部では板厚方向の剥がれが認められた。なおフォーム板には裏 側の盛り上がりに対応した凹みが見られた。

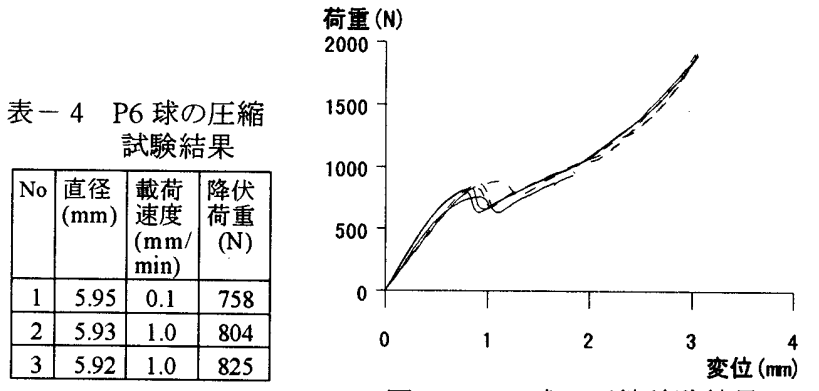

図-6 P6 球の圧縮試験結果
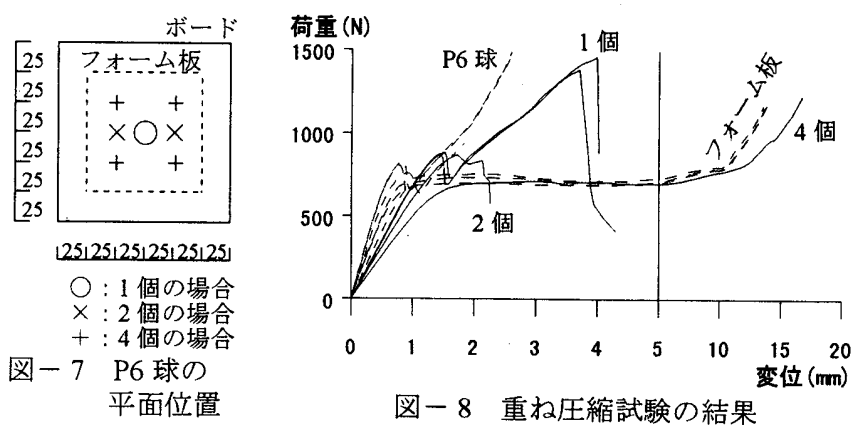

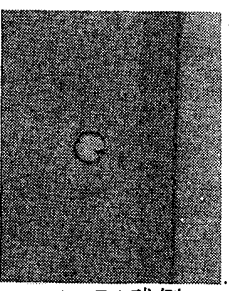

(a) P6 球側

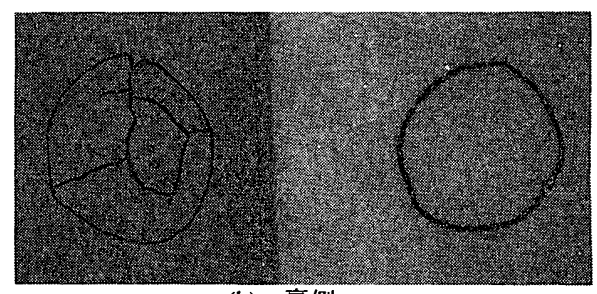

(b) 裏側
写真 -4 P6 球 1 個の重ね圧縮試験の損傷 
(2).P6 球 2 個の試験では、荷重 $1730 \mathrm{~N}$ でボードが短尺方向に曲げ破 壊した。破壊荷重はP P6 球 1 個あたりにすると(1に比べて小さい。 (3) P6 球 4 個の試験では、フォーム板が降伏した後、荷重がさらに 上昇して P6 球 1 個あたり $1230 \mathrm{~N}$ で試験を中止した。P6 球には 素材試験と同様な割れおよびつぶれが見られた。 これらの結果から、静止状態で均等な荷重を受ける P6 球の間隔が $5 \mathrm{~cm}$ 以内であれば、フォーム板の降伏やそれに伴う荷重集中の緩和 を期待できると思われる。仮に荷重集中を無視して $1 \mathrm{~m}^{2}$ あたりの 荷重に換算すると、フォーム板の圧縮降伏が $30 \mathrm{tt} / \mathrm{m}^{2}$ 、維横 $12 \mathrm{~cm}$ 間 隔の:F25 球の爆裂が $190 \mathrm{tf} / \mathrm{m}^{2}$ 程度、密に敷き詰めた P6 球の降伏が $2600 \mathrm{tf} / \mathrm{m}^{2}$ 程度であり、いずれも軽量建物のべた基礎面積当たりの 自重に比べて十分大きいが、 $30 \mathrm{tf} / \mathrm{m}^{2}$ 以上の荷重集中はフォーム板 の降伏によって大きく緩和されると期待される。

上下 2 枚のボードの間に 4 個の球を挿入して上載荷重を与え、室 内に 20 時間または 600 時間放置したクリープ試験の結果を表一 5 に示す。F25 球および P6 球の場合とも、球の損傷は特になく、ボ 一ドに球面状の凹みが生じ、20 600 時間の間で凹み哚さが 2 割 程度増加した。大きくはないがクリープがあると言える。上載荷重 を、球面状の凹みを仮定して求めた接触平面積で除して求めた接触 面圧は、40〜80MPa 程度と素材試験の曲げ強度をやや上回った。 なお P6 球の場合に素材試験と異なりボード側が変形した理由とし ては、クリープ試験および次の小型加振試験ではボードのロットが 他試験と異なるために板厚方向特性が相違した可能性が考えられる。 樹脂球の材料劣化については、フェノール樹脂拉よびポリスチレン とも耐薬品性に優れており ${ }^{6)}$ 、想定使用条件では紫外線による劣化 7)も少ないと考えられる。ただし長期間水中に浸漬させない必要が あろう。

表一5. クリーブ試験の結果

\begin{tabular}{|c|c|c|c|c|c|}
\hline 球 & $\begin{array}{l}\text { 上載荷重 } \\
\text { (N/球) }\end{array}$ & $\begin{array}{l}\text { 放置時 } \\
\text { 間* (h) }\end{array}$ & $\begin{array}{l}\text { ボードの } \\
\text { 凹み(mm) }\end{array}$ & $\begin{array}{l}\text { 球のつぶれ } \\
(\mathrm{mm})\end{array}$ & $\begin{array}{l}\text { 上載荷重/接触 } \\
\text { 平面積** }(\mathrm{MPa})\end{array}$ \\
\hline \multirow{3}{*}{$\begin{array}{l}\text { F25 球+ } \\
\text { ボード }\end{array}$} & 570 & $20[600]$ & $0.16[0.19]$ & \multirow{3}{*}{ 特になし } & $46[38]$ \\
\hline & 1080 & $20[600]$ & $0.25[0.33]$ & & $56[42]$ \\
\hline & 1460 & $20[600]$ & $0.31[0.40]$ & & $61[47]$ \\
\hline \multirow{3}{*}{$\begin{array}{l}\text { P6 球+ } \\
\text { ボード }\end{array}$} & 53 & $20[600]$ & $0.03 ?$ & \multirow{3}{*}{ 特になし } & $?$ \\
\hline & 100 & $20[600]$ & $0.08[0.10]$ & & $67[54]$ \\
\hline & 210 & $20[600]$ & $0.14[0.16]$ & & $81[72]$ \\
\hline
\end{tabular}

* : 温度(湿度)は、 $20 \mathrm{~h}$ が $17-19^{\circ} \mathrm{C}(67-85 \%) ; 600 \mathrm{~h}$ が $13-24^{\circ} \mathrm{C}(36-76 \%)$ **:球面状の凹みを仮定して求めた

表一 6 小型加振試験の結果

\begin{tabular}{|c|c|c|c|c|c|}
\hline 球 & \begin{tabular}{|c} 
平均上載 \\
荷重 \\
(N/球)
\end{tabular} & \begin{tabular}{|l} 
加振 \\
周波数 \\
$(\mathrm{Hz})$
\end{tabular} & \begin{tabular}{|c} 
最大応答 \\
加速度* \\
(gal)
\end{tabular} & $\begin{array}{c}\text { ボードの筋状損傷 } \\
\text { (最大凹み }\end{array}$ & 球の損傷 \\
\hline \multirow{4}{*}{ F25 球 } & 51 & \multirow{4}{*}{$1,1.5,2$} & 20 程度 & 若干の変色 & \multirow{4}{*}{ 特になし } \\
\hline & 100 & & 30 程度 & 若干の転がり跡(0.05) & \\
\hline & 250 & & 35 程度 & 明瞭な転がり跡 $(0.2)$ & \\
\hline & 490 & & 60 程度 & 顕著な転がり跡 $(0.8)$ & \\
\hline \multirow{9}{*}{ P6 球 } & 13 & 1150 & 25 程度 & 若干の変色 & \multirow{3}{*}{ 特になし } \\
\hline & 27 & $1,1.5,2$ & 30 程度 & 若干の転がり跡(0.02) & \\
\hline & 51 & \multirow{3}{*}{$2 * *$} & 40 程度 & 明瞭な転がり跡 $(0.08)$ & \\
\hline & 100 & & 50 程度 & 明瞭な転がり跡 $(0.2)$ & わずかなしわ \\
\hline & 250 & & 200 程度 & 削れ $(0.6)$ & 原型とどめず \\
\hline & 100 & \multirow{4}{*}{ 略円形 } & & 若干の転がり跡(0.03) & 特になし \\
\hline & 160 & & & 若千の転がり跡 $(0.05)$ & 剥がれ*** \\
\hline & 250 & & & 明瞭な転がり跡 $(0.4)$ & 剥がれ \\
\hline & 490 & & & 明瞭な転がり跡 $(0.4)$ & 割れ・つぶれ \\
\hline
\end{tabular}

**: 加振振幅が士25mmに達した後の值

***：P6 球が剥がれた位置のみボードに明睹な跡(0.4)があった。
上下 2 枚のボードの間に 4 個の球を挿入して小型振動台上に置き、 上載重量を乗せて水平 1 方向に正弦波加振する試験(小型加振試験 と呼ぶ)を行った。加振振動数は $1.0,1.5$ または $2.0 \mathrm{~Hz}$ とし、振幅を 0〜 $25 \mathrm{~mm}$ まで潮增させた(それぞれ最大加速度は 100, 220,390gal 相当、最大速度は $16,24,31 \mathrm{~cm} / \mathrm{s}$ に相当)。試験結果を表一 6 に示す が、加振振動数による相違は特になかった。F25 球 (P6 球)を用い た試験では、球あたりの平均上載荷重 $100 \mathrm{~N}(30 \mathrm{~N})$ 程度でボードに 筋状の若干の凹みが生じて応答加速度の増加が見られ、500N (250N) 程度ではボード側に破片および梁さ $0.6 \mathrm{~mm}$ 以上の顕著な転 がり跡 (削れ) が生じて応答加速度が 60gal (200gal) 程度に增加した。 ただし応答加速度の值は、転がり軌跡が 1 方向加振のためほぼ同一 線状になっており、後述の 3 軸振動台実験の結果とは単純な比較が しにくいと思われる。例えば球が同一線状の凹みに沿って転がる場 合、凹み両端では面接触に近いが、中間ではより線接触に近くなる と考える必要があろう。なお後述の試験で生じた P6 球表面のはが れは認められなかったが、加振ではなく人力により略円形の軌跡を 与えたところ、球あたり上載荷重 $160 \mathrm{~N}$ 程度で $\mathrm{P} 6$ 球表面のはがれ が認められた(表一 6 参照)。

\section{4. 加振、計測、試験一覧}

加振波は以下の 5 種類とした。K100:神戸海洋気象台記録を模 擬した 3 方向の振動台加振波。K50：K100を50\%に縮小したもの。 $\mathrm{K} 100 \mathrm{H}: \mathrm{K} 100$ の水平 2 方向成分だけを取り出したもの， BCJ：レ ベル 2 の建築センター波(BCJ-L2)を 70\%に縮小して模擬した波。 $\mathrm{SIN}: 2 \mathrm{~Hz}$ の正弦波で振幅を徐々に大きくしたもの。な拉必要に応 じてワイヤ引張による静的加力 STA を行った。使用した振動台の 定格は、最大加速度が南北 $1 \mathrm{G} \cdot$ 東西 $3 \mathrm{G} \cdot$ 上下 $1 \mathrm{G}$ 、最大変位が南北 $\pm 300 \mathrm{~mm} \cdot$ 東西 $\pm 150 \mathrm{~mm} \cdot$ 上下 $\pm 100 \mathrm{~mm}$ で、テーブル寸法は南北 $6 \mathrm{~m} \cdot$ 東西 $4 \mathrm{~m}$ である。

測定項目は、下基礎および上基礎の 3 方向絶対加速度、上基䃈一 下基礎間の水平相対変位(光学式変位計による)、上基礎の水平絶対 変位(ワイヤ式変位計による)、振動台の 3 方向の絶対加速度および 変位(振動台浮き基礎からの相対変位)である。測定時間間隔は 1/100 秒とし、 $50 \mathrm{~Hz}$ 以上ではフィルタをかけた。静的加力では引張 荷重も測定した。測定位置を図一2 中に示す。

実施した試験の一覧を実施順に表一7に示す。主なバラメータは、 免震タイプ、質量偏心、加振波、ばねの本数(偏心)、ブレーキ油圧 である。質量偏心がある試験(試験名に-EM を付す)では、付加重量 を南側へ約 $840 \mathrm{~mm}$ 移動させた。この場合、仮に免震層の夙性を重 量分布と無関係に平面的に一様と考え、質量偏心の率を、重心のず れを上基礎平面の $(\text { 極 } 2 \text { 次モーメント/面積 })^{0.5}=1.76 \mathrm{~m}$ で除した值と 定義するなら、質量偏心の率は 0.17 となる。ばねの偏心の率は、 ばね重心のずれを同様に $1.76 \mathrm{~m}$ で除した值と定義するなら、ばねが 全て $(8$ 本)ある場合で 0.19、北西側装置内の 4 本を外した場合(試験 名に-ES を付す)で 0.93 となる。なお P6 タイプの試験名の最後に-2 または-3 を付した試験は、光学式変位計の光を P6 球が横切って測 定上の問題が起きた事による再試験を示す。ブレーキによる摩擦力 の合計は、油圧から装置自重分 $2.2 \mathrm{kgf} / \mathrm{cm}^{2}$ を除いた值に摩擦係数拄 よび $616 \mathrm{~cm}^{2}$ を乗じた值として計算される。実験状況を写真一 5 に 示す。 
表ー7 実施した武験の一覧

\begin{tabular}{|c|c|c|c|c|c|c|c|c|c|}
\hline $\begin{array}{l}\text { F25 タイプ } \\
\text { 試験名 } \\
\text { (実施順) }\end{array}$ & $\begin{array}{l}\text { 华 } \\
\text { 量 } \\
\text { 偏 } \\
\text { 心 }\end{array}$ & 加振 ${ }^{* 1}$ & $\begin{array}{l}\text { ば } \\
\text { ね } \\
\text { 本 } \\
\text { 数 }\end{array}$ & $\begin{array}{l}\text { 油压 } \\
(\mathrm{kgf} \\
\left./ \mathrm{cm}^{2}\right)\end{array}$ & $\begin{array}{l}\mathrm{P6} \text { タイプ } \\
\text { 試験名 } \\
\text { (実施順) }\end{array}$ & $\begin{array}{l}\text { 質 } \\
\text { 量 } \\
\text { 偏 } \\
\text { 心 }\end{array}$ & 加振 & $\begin{array}{l}\text { ば } \\
\text { 标 } \\
\text { 本 } \\
\text { 数 }\end{array}$ & $\begin{array}{l}\text { 油压 } \\
(\mathrm{kgf} \\
\left./ \mathrm{cm}^{2}\right)\end{array}$ \\
\hline F-K50 & \multirow{12}{*}{ 無 } & $\mathrm{K} 50$ & \multirow{8}{*}{8} & \multirow{8}{*}{ OFF } & P-STAl & \multirow{11}{*}{ 無 } & \multirow{3}{*}{ STA } & \multirow{2}{*}{0} & OFF \\
\hline $\mathrm{F}-\mathrm{K} 100$ & & $\mathrm{~K} 100$ & & & P-STA1-BR & & & & 6,12 \\
\hline $\mathrm{F}-\mathrm{K} 75$ & & $\mathrm{~K} 75$ & & & P-STAI-SP & & & \multirow{7}{*}{\multicolumn{2}{|c|}{ OFF }} \\
\hline $\mathrm{F}-\mathrm{Kl} 00-2$ & & $\mathrm{~K} 100$ & & & P-K50 & & $\mathrm{K} 50$ & & \\
\hline $\mathrm{F}-\mathrm{K} 100 \mathrm{H}$ & & $\mathrm{K} 100 \mathrm{H}$ & & & $\mathrm{P}-\mathrm{K} 100$ & & & & \\
\hline F-BCJ65 & & $\mathrm{BCJ} 65$ & & & P-K100-2 & & $\mathrm{K} 100$ & & \\
\hline $\mathrm{F}-\mathrm{BCJ}$ & & $\mathrm{BCJ}$ & & & P-K100-3 & & & & \\
\hline F-STA2-SP & & \multirow{3}{*}{ STA } & & & $\mathrm{P}-\mathrm{K} 100 \mathrm{H}$ & & $\mathrm{K} 100 \mathrm{H}$ & & \\
\hline F-STA2-BR & & & \multirow{2}{*}{0} & 9 & P-BCJ & & $\mathrm{BCJ}$ & \multirow[t]{3}{*}{8} & \\
\hline F-STA2-BR-2 & & & & 12 & $\mathrm{P}-\mathrm{K} 50-\mathrm{BR}^{* 3}$ & & $\mathrm{~K} 50$ & & \multirow{2}{*}{$17^{* 4}$} \\
\hline F-K50-BR & & $\mathrm{K} 50$ & \multirow{2}{*}{\multicolumn{2}{|c|}{$17^{* 2}$}} & P-K100-BR & & $\mathrm{K} 100$ & & \\
\hline $\mathrm{F}-\mathrm{K} 100-\mathrm{BR}$ & & $\mathrm{K} 100$ & & & P-K50-EM & \multirow[b]{4}{*}{ 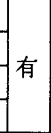 } & $\mathrm{K} 50$ & & \multirow{10}{*}{ OFF } \\
\hline F-K50-EM & \multirow{5}{*}{ 有 } & $\mathrm{K} 50$ & \multirow{5}{*}{8} & \multirow{10}{*}{ OFF } & P-K100-EM & & $\mathrm{K} 100$ & & \\
\hline F-K100-EM & & $\mathrm{K} 100$ & & & P-K100H-EM & & \multirow{2}{*}{\multicolumn{2}{|c|}{$\mathrm{K} 100 \mathrm{H}$}} & \\
\hline F-K100H-EM & & $\mathrm{K} 100 \mathrm{H}$ & & & P-K100H-EM-2 & & & & \\
\hline F-K100-EM-2 & & $\mathrm{K} 100$ & & & P-K50-ES & \multirow{7}{*}{ 無 } & K50 & \multirow{4}{*}{4} & \\
\hline F-BCJ-EM & & $\mathrm{BCJ}$ & & & P-K100-ES & & K100 & & \\
\hline F-K50-ES & \multirow{5}{*}{ 無 } & $\mathrm{K} 50$ & \multirow{3}{*}{4} & & P-K100H-ES & & \multirow{2}{*}{$\mathrm{K} 100 \mathrm{H}$} & & \\
\hline F-K100-ES & & $\mathrm{K} 100$ & & & P-K100H-ES-2 & & & & \\
\hline $\mathrm{F}-\mathrm{K} 100 \mathrm{H}-\mathrm{ES}$ & & $\mathrm{K} 100 \mathrm{H}$ & & & P-STA3-SP & & \multirow[b]{2}{*}{ STA } & 8 & \\
\hline F-STA3 & & \multirow{2}{*}{ STA } & 0 & & P-STA3 & & & 0 & \\
\hline F-STA3-SP & & & 8 & & P-SIN-BR35 & & SIN & 8 & $35^{* 5}$ \\
\hline
\end{tabular}

*1：K75はK100を75\%に縮小、BCJ65 はBCJを65/70に縮小した。

*2: 加振後の值は F-K50-BR で 14 程度。

*3 : 過去に飛び出した P6 球を P6 球が少ない箅所に戻した後に試験した。

*4: 加振後の值は P-K100-BR で 12 程度。

*5: 加振中は 36 〜 40 で振動し、加振後の值は 34 であった。

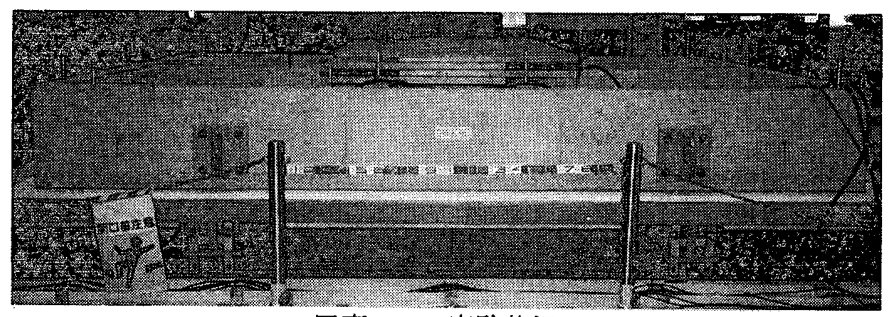

写真 -5 実験状況

\section{F25タイプの試験}

F25 タイプ試験終了後の状況を写真一 6 に示す。上基礎下面のボ 一ドが部分的に破損して(写真(a),(b))、層状の破片が生じ(写真(c))、 大型の破片も見られた(写真(d))。F25 球による荷重分担が均一でな く、一部に荷重が集中して、ボードが局部的に板厚方向に剥がれた と判断される。板厚方向の剥がれはボード素材試験でも見られてお り、ボードの素材特性に起因すると思われる。下基礎上面のコンク リートには荷重集中部分に最大で幅 $3 \mathrm{~mm}$ 程度の F25 球の転がり跡 が見られた。一方、荷重集中があまりなかった䇢所ではボードに茶 色の筋がついた程度であった(写真(b)の最下部)。試験体の上下応答 を無視した球あたり上載荷重の平均值は $136 \mathrm{~N}$ であるが、茶色の筋 は小型加振試験の $50 \mathrm{~N} /$ 球 程度の損傷状況とある程度似ている。剥 がれた箇所での荷重集中の程度は不明であるが、小型加振試験結果 から推察すると $500 \mathrm{~N} /$ 球 程度以上と思われる。

試験結果の概要を表 -8 の左半に示す。各試験とも加速度の頭打 ちによる免震効果が認められる。すべり変位の最大值は $25 \mathrm{~cm}$ 程度 で、残留すべり変位は、ブレーキ力を作用させた試験およびばねを 外した試験を除けば大略 $3 \mathrm{~cm}$ 以下であった。質量偏心・ばねの本 数(偏心)・ブレーキ油圧を変化させた場合の傾向は後述の P6 タイ ブとほぼ同様であったため、以下 F25 タイプの試験結果に特有の
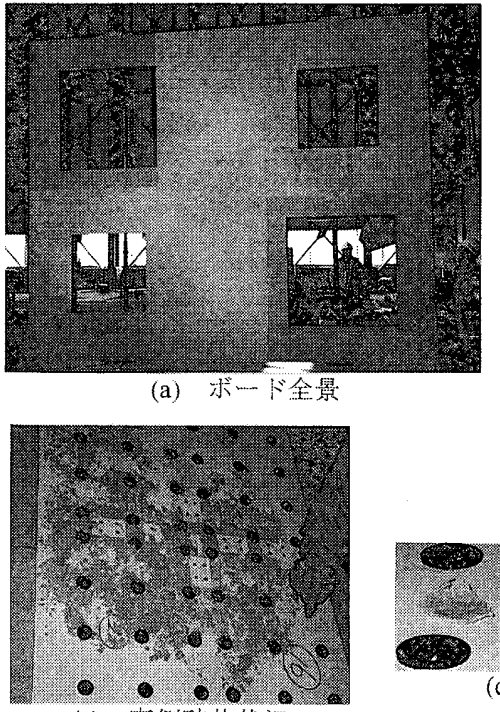

(c) 南側破片状況

写真一 6 F25 タイプの試験終了後状況

表 -8 水平加速度オービットの半径およびすべり変位

\begin{tabular}{|c|c|c|c|c|c|c|c|}
\hline \multirow{2}{*}{$\begin{array}{l}\text { F25 タイプ } \\
\text { 試験名 } \\
\text { (実施順) }\end{array}$} & \multirow{2}{*}{$\begin{array}{l}\text { 加速 } \\
\text { 度の } \\
\text { 半径 } \\
\text { (gal) }\end{array}$} & \multicolumn{2}{|c|}{ すべり変位 } & \multirow{2}{*}{$\begin{array}{l}\text { P6 タイプ } \\
\text { 試験名 } \\
\text { (実施順) }\end{array}$} & \multirow{2}{*}{$\begin{array}{l}\text { 加速 } \\
\text { 度少 } \\
\text { 半径 } \\
\text { (gal) }\end{array}$} & \multicolumn{2}{|c|}{ すべり変位 } \\
\hline & & $\begin{array}{l}\text { 最大 } \\
\text { (cm) }\end{array}$ & $\begin{array}{l}\text { 残留 } \\
(\mathrm{cm})\end{array}$ & & & $\begin{array}{l}\text { 最大 } \\
\text { (cm) }\end{array}$ & $\begin{array}{l}\text { 残留 } \\
(\mathrm{cm})\end{array}$ \\
\hline $\mathrm{F}-\mathrm{K} 50$ & 110 & 12.2 & 3.2 & P-K50 & 25 & 12.2 & 2.2 \\
\hline $\mathrm{F}-\mathrm{K} 100$ & 105 & 24.5 & 1.9 & $\mathrm{P}-\mathrm{K} 100$ & 45 & 25.4 & 1.9 \\
\hline F-K75 & 55 & 18.2 & 1.0 & P-K100-2. & 40 & 24.5 & 2.6 \\
\hline $\mathrm{F}-\mathrm{K} 100-2$ & 60 & 24.6 & 1.8 & P-K100-3 & 40 & 24.7 & 2.2 \\
\hline $\mathrm{F}-\mathrm{K} 100 \mathrm{H}$ & 60 & 25.6 & 1.8 & P-K100H & 40 & 24.8 & 2.8 \\
\hline $\mathrm{F}-\mathrm{BCJ}$ & $55^{*}$ & 24.0 & 1.1 & P-BCJ & $35^{*}$ & 26.6 & 2.4 \\
\hline F-K50-BR & 120 & 12.7 & 2.6 & P-K50-BR & 95 & 13.5 & 4.8 \\
\hline F-K100-BR & 115 & 21.6 & 4.8 & P-K100-BR & 100 & 23.0 & 8.8 \\
\hline $\mathrm{F}-\mathrm{K} 50-\mathrm{EM}$ & 55 & 10.8 & 0.3 & P-K50-EM & 20 & 12.1 & 2.1 \\
\hline F-K100-EM & 65 & 22.5 & 0.6 & P-K100-EM & 40 & 25.1 & 0.7 \\
\hline $\mathrm{F}-\mathrm{K} 100 \mathrm{H}-\mathrm{EM}$ & 60 & 24.8 & 0.8 & P-K100H-EM & 40 & 24.9 & 1.8 \\
\hline $\mathrm{F}-\mathrm{K} 100-\mathrm{EM}-2$ & 60 & 26.1 & 1.0 & P-K100H-EM-2 & 40 & 24.8 & 1.9 \\
\hline F-BCJ-EM & $55^{*}$ & 20.8 & 1.6 & P-K50-ES & 20 & 12.0 & 2.4 \\
\hline F-K50-ES & 45 & 12.5 & 0.8 & P-K100-ES & 35 & 26.8 & 1.8 \\
\hline F-K100-ES & 55 & 24.7 & 6.5 & P-K100H-ES & 40 & 27.0 & 3.1 \\
\hline $\mathrm{F}-\mathrm{K} 100 \mathrm{H}-\mathrm{ES}$ & 55 & 27.4 & 0.8 & P-K100H-ES-2 & 35 & 26.0 & 3.7 \\
\hline
\end{tabular}

事項を中心にして記す。なお各試験とも上基礎の鉛直方向加速度は 下基礎とほとんど同じであった。

F-K50 および F-K100-2 について、下基礎および上基礎の絶対加 速度時刻歴を図ー9に点線および実線で示し、上基礎の絶対加速度 および、上基礎の下基礎に対する相対すべりのオービットを図一 10 に示す。ただし加速度およびすべりは平面中心位置に換算して あり、X方向は北を正、Y 方向は西を正とした。両図から以下のこ とがわかる。

(1)上基礎の水平加速度には、免震効果による頭打ちが見られる(図 - 9)。しかし最初の加振である F-K50 の0〜 2.5sec では、上基 礎の水平加速度の大きさが下基礎の 3 倍程度に増幅されている (図一 9(a))。この増幅現象は F-K100-2(正確には F-K75 以後の試 験)では見られておらず(図一 9(b))、ボードの剥がれによってこの 現象が起きなくなったと考えられる。初期の増幅原因は特定でき ないが、初期状態ではボードに素材試験(写真ー 2)やクリーブ試 験で認められた球面状の凹みが存在し、応答を増幅したと推察さ れる。

(2)加速度オービットの大きさは最初の加振の F-K50 では約 $110 \mathrm{gal}$ 

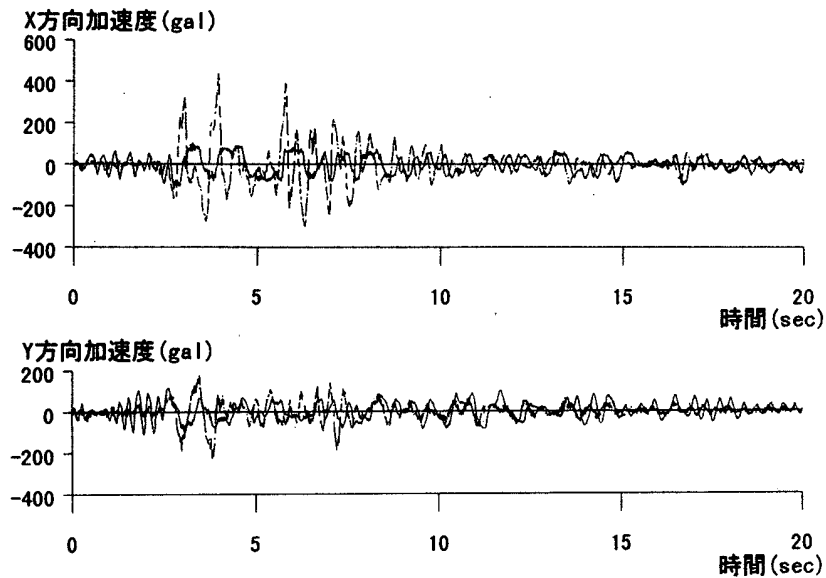

(a) $\mathrm{F}-\mathrm{K} 50$
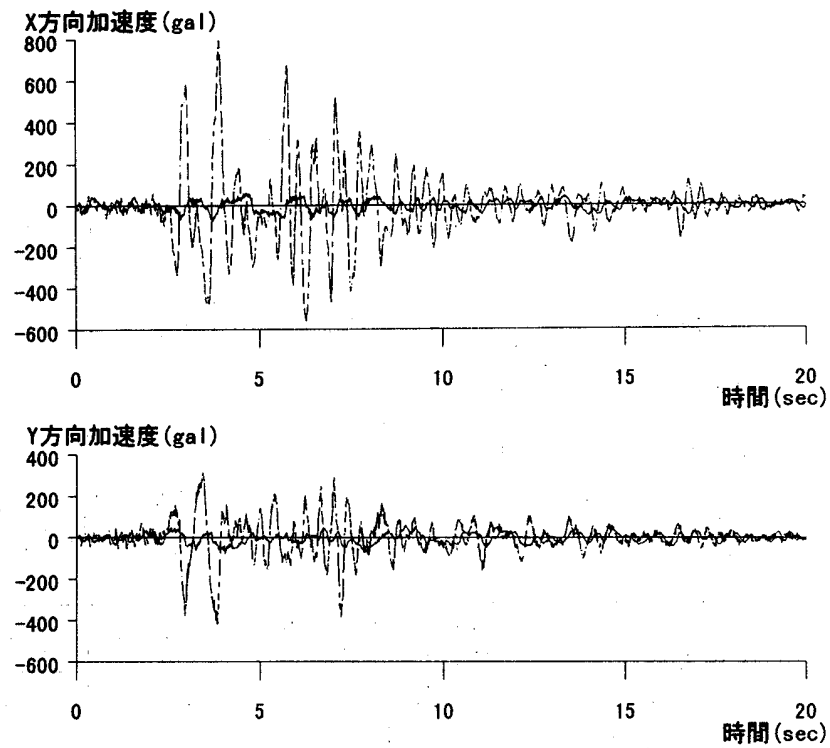

(b) F-K100-2

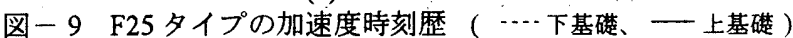

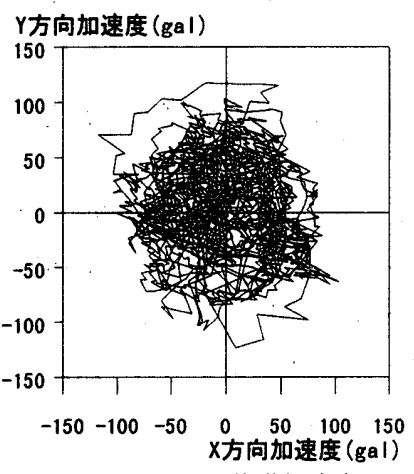

(a) F-K50 上基䃈加速度

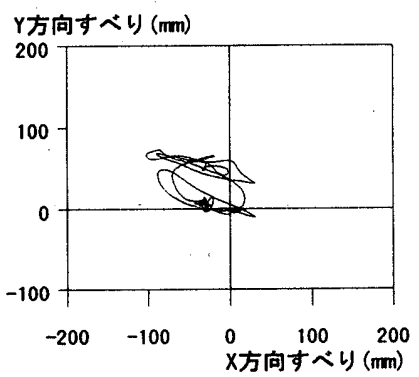

(c) F-K50すべり

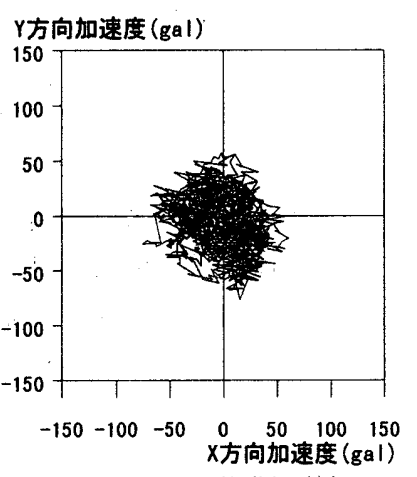

(b) F-K 100-2 上基礎加速度

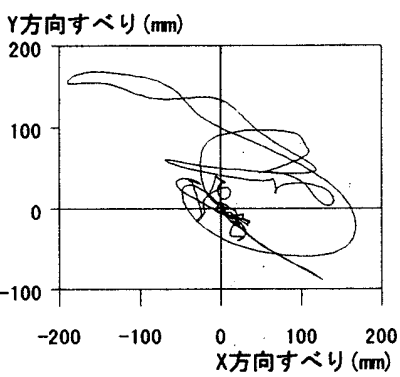

(d) F-K100-2 オべり
図ー10 加速度およびすべり変位のオービット(F25 タイプ)

(図- 10(a))、F-K100-2(正しくは F-K75 以後の試験)では約 60gal (図一 10(b))となっており、入力が小さい F-K50 の方が大きい。 この逆転現象もボードの剥がれに起因すると思われる。表一 8 の F-K100 と F-K 100-2 の応答加速度の相違はボードの剥がれによる と判断され、剥がれが結果的に再加振時の荷重集中を緩和して忘 答加速度を低減させたと考えられる。しかしボードの剥がれは上 基礎一下基礎間の時々刻々の相対不陸にも関係しており、本夕イ プでは実施工における不陸分布の定量化や、不陸に起因するねじ れ応答の設計上の評価に課題が残されていると言える。

\section{P6タイプの試験}

P6 タイプの試験後の状況を写真一 7 に示す。 K100 および K100H 加振では、周辺部の P6 球が外周へ飛び出す状況が見られた。なお K50 加振では P6 球の飛び出しはごくわずかであった。飛び出した P6 球を集めて P6 球が少ない箇所に戻す修正作業を 6 加振(P-K50 P-BCJ)終了後に行った。6 加振終了後のP6 球の状況を写真(a)に、 全試験終了後の状況を写真(b)に、その中央部詳細を写真(c)に、周 辺部詳細を写真(d)にそれぞれ示す。写真(a)と(b)はよく似ており、 周辺部では P6 球が少なくなっているが、中央部では密に近い部分 が多い。なお最終時に残った P6 球は計 $24: 0 \mathrm{~kg}$ となったが、これに は加振回数が多い事および上基礎が開口を有する事が関倸している。 全試験終了後の塑性化状況を見ると、フォーム板には、下基礎側ボ 一ド継目の隙間に応じた高さ約 $1 \mathrm{~mm}$ の盛り上がりや、F25 タイプ の実験で生じたコンクリート面の転がり跡の反転による盛り上がり が認められた(写真(e)）。一方、ボードには目視できる損傷がなく、 コンクリート面にも新たな損傷はなかった。P6 球はごく一部で、 表面が層状に剥がれたものが見つかったが、その数は 20 個程度と 非常に少なかった(写真(f))。P6 球の層状の剥がれは、弾性接触理論 によれば最大せん断応力点が球内部にあるので、転がり時にそれが 移動したと考えれば説明できる。試験体の上下応答抢よび P6 球の 減少を無視すれば、球あたり上載荷重の平均値は $0.38 \mathrm{~N} /$ 球で、フォ 一ム板の不陸吸収は $10 \mathrm{~N} / \mathrm{x}^{\mathrm{a}}$ であるから、ごく単純には 30 倍程度 以上の荷重集中があったと推察される。なお小型加振試験では 160 N/球 で P6 球の剥がれが見られたが、本試験ではボード継目が影

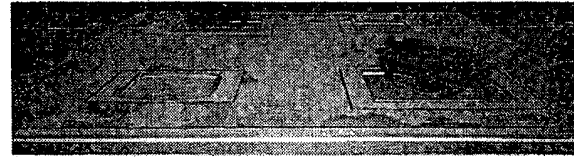

(a) 6 加振終了後

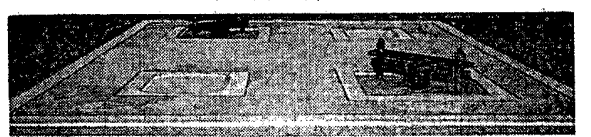

(b) 全試駚終了後

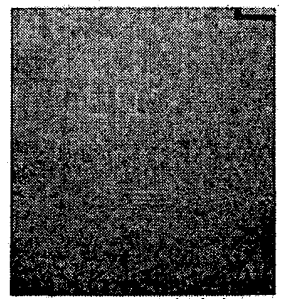

(c) (b) 0 中央部

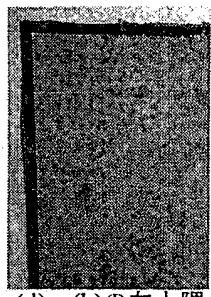

(d) (b) $\sigma$ 左上隅 写真 -7 試験後状況(P6 タイプ)

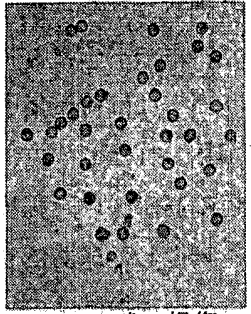

(f) $\mathrm{P} 6$ 球 $の$ 賣甥

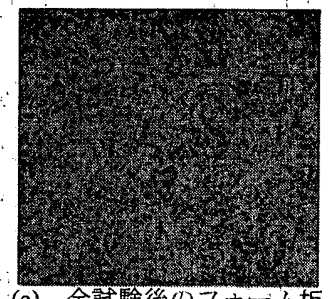

(e) 全試験後けフォーム板 

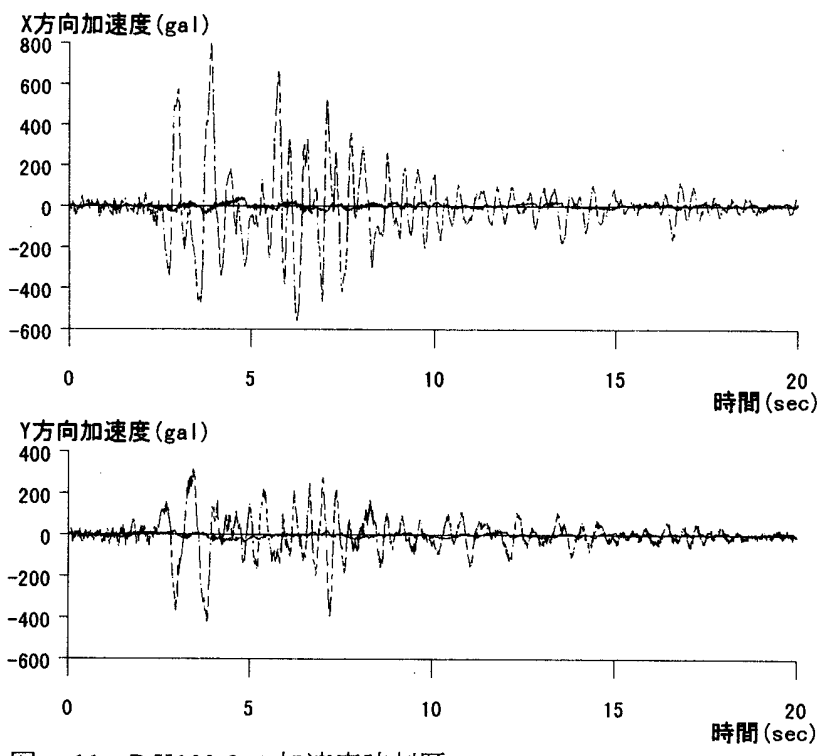

図－11 P-K100-3 の加速度時刻歴（--.下基礎、一上基礎）

響した可能性も考えられる。

試験結果の概要を表一 8 の右半に示す。各試験の応答加速度は F25 タイプに比べて小さい。すべり変位の最大值は $25 \mathrm{~cm}$ 程度で、 残留すべり変位は、ブレーキ力を作用させた試験を除けば大略 $3 \mathrm{~cm}$ 以下となった。残留変位は、入力が小さい方が小さい傾向は特にな く、むしろ入力の後摇れ部分の影響を受けると考えられる。なお各 試験とも上基礎の鉛直加速度は下基礎とほとんど同じであった。

P-K100-3 の下基礎および上基礎の加速度時刻歴を図ー 11 に点線 および実線で示し、P-K50 および P-K100-3 の上基礎加速度および 相対すべりのオービットを図ー 12(a)〜(d)に示す。上基礎の水平加 速度には免震効果による頭打ちが見られ(図ー 11)、加速度オービッ トの半径は P-K50 で大略 25gal(図- 12(a))、P-K100-3 で大略 40gal (図ー12(c))と非常に小さい。なお加速度オービットの形状はきれい な円形ではないが、これは変位に略比例してばねの復元力が増加す る事(変位 $250 \mathrm{~mm}$ だと $19 \mathrm{gal}$ 程度)、および下基礎に上向き加速度が 作用すると両基礎間の見かけの転がり摩擦係数が増加する事が原因 として考えられる。図一 13(a)に P-K100-3 の振動台変位および上基 礎絶対変位の時刻歴を点線および実線で示し、図(b)にねじれ回転 角の時刻歷を実線で示す。上基礎変位が振動台変位に比べて小さか った事、ねじれはむしろ小さかった事がわかる。

水平 2 方向加振による $\mathrm{P}-\mathrm{K} 100 \mathrm{H}$ のオービットを図ー 12(e),(f)に示 すが、3 方向加振の P-K100-3 の結果とほとんど変わらない。

ブレーキ作動状態で加振した P-K50-BR のオービットを図ー $12(\mathrm{~g}),(\mathrm{h})$ に示し、ねじれの時刻歴を図一 13(c)k点線で示す。ブレ一 キにより加速度オービットの半径は 95gal 程度に增大したが、依然 として良好な加速度低減効果を示しており、权じれも大きくない。

質量を偏心させた P-K100-EM のすべりのオービットを図ー12(i) に示し、ねじれの時刻歷を図ー13(b)に点線で示す。オービットは 偏心のない P-K100-3 とほとんど同じであり、权じれの増大もなか った事から、質量偏心による影響は小さいと判断される。これは上 基礎と下基礎間の転がり摩擦係数が質量偏心の影響をあまり受けな いと考えると容易に説明できる。

北西側装置内のばねを全て外した P-K100-ES のすべりのオービ

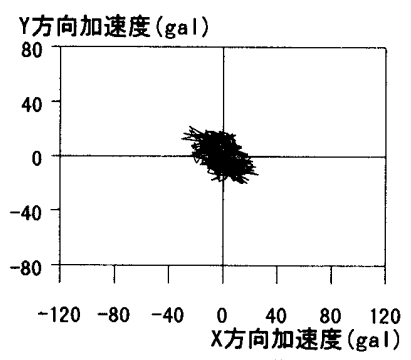

(a) P-K50 上基礎加速度

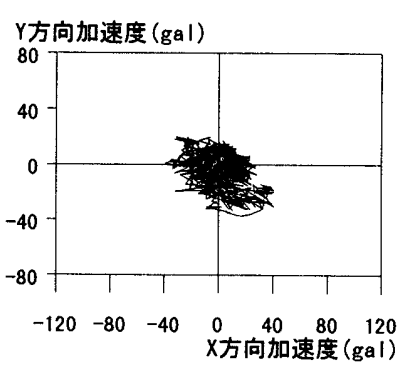

(c) P-K100-3 上基礎加速度

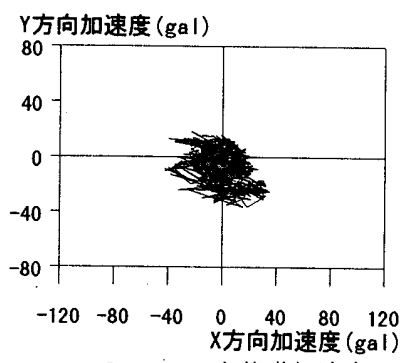

(e) $\mathrm{P}-\mathrm{K} 100 \mathrm{H}$ 上基礎加速度

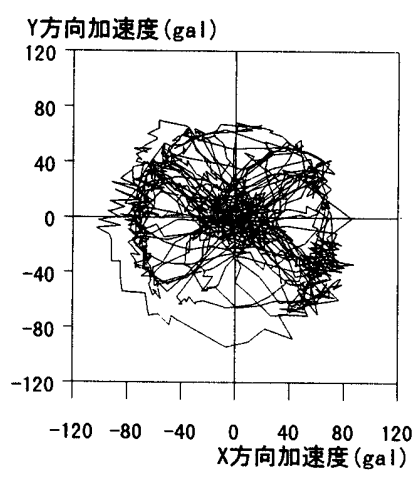

（g） P-K50-BR 上基礎加速度

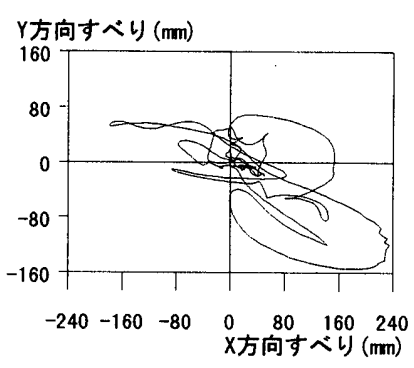

(j) P-K100-ESすバり

図一 12 加速度およびす心゙り変位のオービット(P6 タイプ)

ットを図ー12(j)に示すが、オービットがいくらか右下にずれてい る。ねじれの時刻歴を図ー 13(c)に実線で示すが、ばねがねじれを 拘束しない場合、大きなねじれが生じる事がわかる。

上基礎絶対加速度とすべり变位の関係を図ー 14 に示す。ただし 1 方向加振した P-BCJ では X 万向の関係を示し、他の試験ではす 

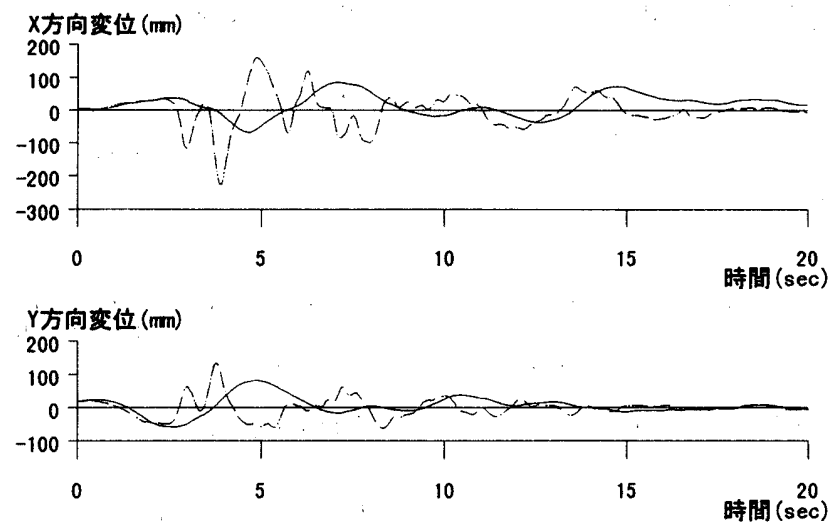

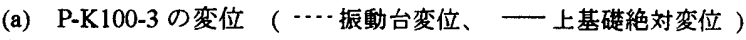

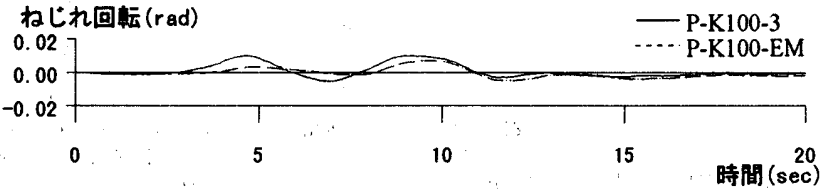

(b) P-K100-3および P-K100-EMのねじれ

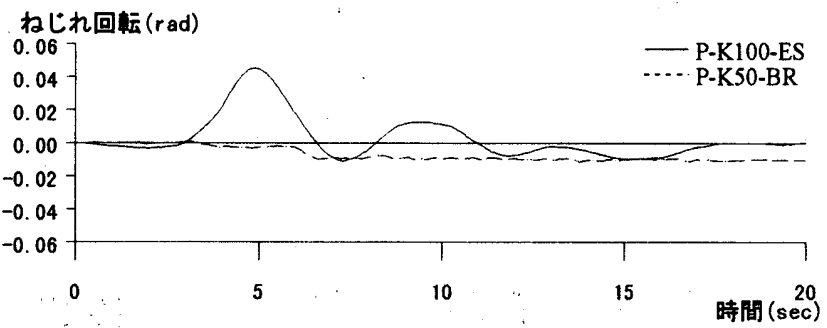

(c) P-K100-ES および P-K50-BRのねじれ

図一 13 変位およびねじれの時刻歴

ベり変位の主軸方向に近いX $-30^{\circ} \mathrm{Y}$ 方向の関係を示す。図では加速度 の符号を逆符号にして、慣用の荷重変位曲線の向きと合わせてある。 なおX- $30^{\circ} \mathrm{Y}$ 方向でなくノルムにする方法も考えられるが、ばねの復 元力による加速度があるため加速度ノルムにする意味は薄い。図を 見ると、すべり後の勾配がばねによる勾配とほぼ一致している事、 変位が大きいとループ形状がやや広がる事がわかる。後者はフォー 厶材を圧縮する時に転がり抵抗がやや増加すると考えると容易に説 明できる。なお P-K100-EM を.P-K100-3 と比べるとループ形状が若 干細くなっている。多数回の加振もしくは P6 球の減少によって転 がり抵抗がやや減少した可能性も考えられる。

以上の実験結果より P6 タイプでは、(1)フォーム材による不陸吸 収が有効に作用して極端な荷重集中を防ぎ、(2)多数回の加振後でも 問題となるような塑性化がなく、(3)質量を偏心させた場合でも称じ れ応答があまり增大しない、という良好な免震性能を示したと判断 される。

\section{7. 結論}

べた基礎を有する軽量建物や戸建住宅を対象に、べた基礎とべた 基礎の下に設けた鉄筋コンクリートスラブ(下基礎)の間に樹脂球を 挿入した新たな免䟴方式について、3 軸振動台実験を行った。

セメント系瀻維補強板を介して直径 $25 \mathrm{~mm}$ のフェノール樹脂球 を縦横 $12 \mathrm{~cm}$ 間隔で挿入した F25 タイプでは、以下の結果が得られ た。(1)初期状態では荷重分担が均一でなく、一部に荷重が集中して、 繊維補強板が局部的に板厚方向に剥がれた。(2)加速度の頭打ちによ

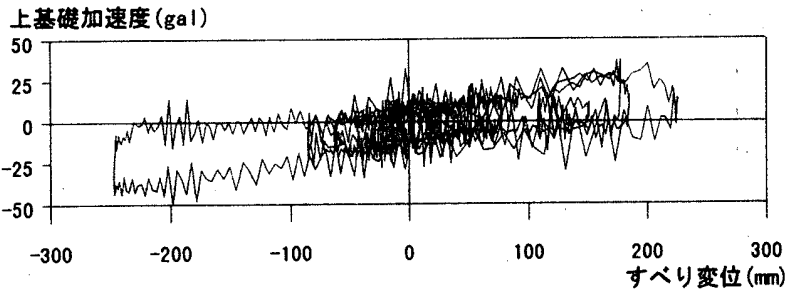

(a) P-K100-3

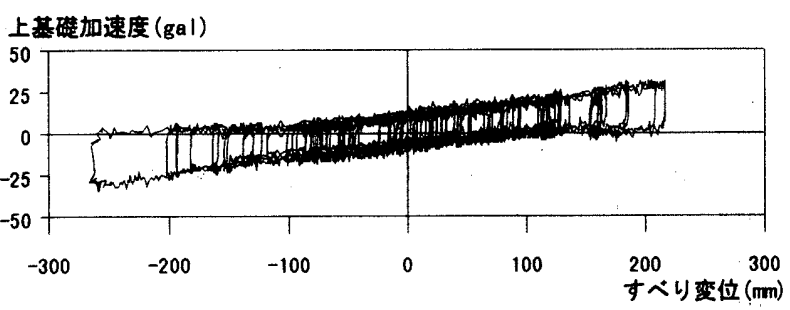

(b) $\mathrm{P}-\mathrm{BCJ}$

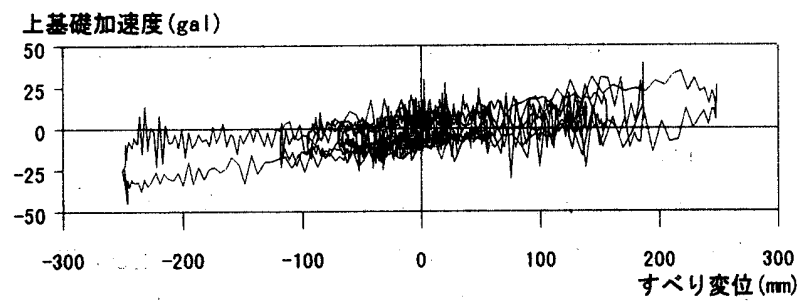

(c) P-K100-EM

図-14 絶対加速度とすべり変位の関係

る免震効果が認められたが、初期状態では小さな入力に対して応答 加速度を 3 倍程度に增幅する場合がある事がわかった。

押出法ポリスチレンフォーム板、繊維補強板、直径 $6 \mathrm{~mm}$ のポリ スチレン樹脂球、瀻維補強板を順に敷き並べたP6 タイプでは、以 下の結果が得られた。(1)フォーム板は、べた基礎の移動に伴って変 化するべた基礎一下基礎間の相対不陸を吸収し、過大な荷重集中や 樹脂球の損傷を防ぎ、応答加速度の低減に役立ったと考えられる。 (2)応答加速度が大略 40gal 程度に低減され、残留変位や変位のねじ れ成分も小さかった。(3)質量偏心による影響は小さいと判断される。 (4)ブレーキ装置の作動状態でも良好な加速度低減効果が得られ、摩 擦ブレ一キは小規模免震建物の望ましい風荷重対策の1つと考えら れる。

本実験結果をもとに、べた基礎を有する軽量建物の免震方式とし て P6 タイプを提案する。解析との比較検討結果は今後報告する予 定である。

\section{参考文献}

1)飯場正紀：免震住宅の性能に関寸る基本的な考え方と住宅用免震装固の特 性、ビルデインダレター: pp.17-27、1999.3

2)新谷隆弘、石丸辰治ほか：ゴム球支承を用いた耐震構造システムに関する基 礶的研究（その1 〜その3）、日本建築学会大会学術講演梗概集 B-2、 pp.505- $510 、 1998.9$

3)飯場正紀、緑川光正ほか：年建住宅用免震装置の振動台実験、日本建築学会 大会学術講演梗概集 B-2、pp.661-662、1998.9

4)木質棈造設計規準·同解説 pl15：日本建築学会、1995.1

5)The 10th Anniversary (EDO10 周年記念誌)、発泡スチロール土木工法開発機 構、 1995.9

6)例えば、伊藤公正編：プラスチックデータハンドブック、工業調查会、 1980

7)例えば、大石不二夫、成沢郁夫：プラスチック材料の寿命一耐久性と破壊一。 日刊工業新閶社、1987 